\title{
Effect of Fertilization on the NPK Uptake of Different Maize (Zea mays L.) Genotypes
}

\author{
P. PEPÓ* and G.L. Karancsi \\ Institute of Crop Science, Agronomy Faculty, University of Debrecen, \\ H-4032 Debrecen, Böszörményi út 138, Hungary \\ (Received 28 November 2016; Accepted 10 May 2017; \\ Communicated by S. Gottwald)
}

\begin{abstract}
In 2013 and 2014, the N, P and K contents of the aboveground phytomass and grain yield of maize hybrids (P 9494, SY Afinity) were examined, as well as the different amounts of N, $\mathrm{P}$ and $\mathrm{K}\left(\mathrm{kg} \mathrm{ha}^{-1}\right)$ uptake at different nutrient levels (control, $\mathrm{N}_{90}+\mathrm{PK}, \mathrm{N}_{150}+\mathrm{PK}$ ), on calcareous chernozem soil in Eastern Hungary $\left(47^{\circ} 33^{\prime}\right.$ N, $21^{\circ} 27^{\prime}$ E). Our experimental findings proved that as a result of fertilization, the macronutrient $(\mathrm{N}, \mathrm{P}, \mathrm{K})$ content of the maize hybrids significantly increased in both years in the vegetative and generative plant parts. In the control, the maize hybrids gave high yields (from 10.2 to $11.3 \mathrm{t} \mathrm{ha}^{-1}$ in 2013 , and 11.3-14.6 tha $\mathrm{ta}^{-1}$ in 2014), and the surpluses due to fertilization varied between 3.2 and $5.0 \mathrm{t}$ $\mathrm{ha}^{-1}(2013)$ and 2.9 and $3.1 \mathrm{tha}^{-1}$ (2014). The experimental results proved that fertiliser dosage, genotype and crop year each influenced the NPK utilisation of the fertiliser applied. With increasing doses of fertiliser, NPK utilization deteriorated. In both years, the SY Afinity gave a better N-utilization than the P 9494 hybrid. P- and K-utilization were significantly affected by the year. N-utilization varied from 49.8 to $97.6 \%$, P-utilization varied from 17.1 to $47.7 \%$, and K-utilization from 26.7 to $79.7 \%$; in 2013 , and the utilization values were 70.9 to $96.8 \%, 11.6$ to $23.3 \%$, and 30.4 to $62.0 \%$ in 2014 , respectively.
\end{abstract}

Keywords: maize, genotype, fertilisers, NPK uptake, NPK utilization

\section{Introduction}

Hungarian crop production is cereal oriented. This means that the combined total sowing area for small grain cereals and maize total some $2.7-2.8$ million hectares $(\sim 70 \%)$. The input of fertilisers, especially nitrogen (and other macroelements, $\mathrm{P}$ and $\mathrm{K}$ ) has promoted consistent and increasing yields for field crops (mainly cereals), but their inefficient use has had harmful environmental problems, including degradation of water quality and increased $\mathrm{NO}_{3}-\mathrm{N}$ accumulation in the soils, as well as higher emissions of greenhouse gases ( $\mathrm{Li}$ et al. 2007; Van Groenigen et al. 2010). The efficient use of fertilisers (NPK) has proven be a major challenge due to crop management practices, variable agrometeorological and soil factors (Ladha et al. 2005; Devkota et al. 2013). Appropriate N-fertilization (dose, timing, splitting and harmonized with PK fertiliser doses) can increase maize yields (Pepó et al. 2006), but increasing N-doses to above optimum dose levels does not *Corresponding author; E-mail: pepopeter@agr.unideb.hu 
result in higher yields (Liu et al. 2003; Pepó et al. 2008) and may even lead to yield reduction (Lü et al. 2011). Thus, proper $\mathrm{N}$ fertiliser management is essential in maintaining high maize yield and $\mathrm{N}$ efficiency. In the international literature, only few papers could be found about the nitrogen use efficiency (NUE) of different maize lines (open pollinated and inbred) and hybrids (Balko and Russell 1980; Muruli and Paulsen 1981; 1982; Akintoye et al. 1999). In cereals, $\mathrm{N}$ uptake efficiency at global level is reported to be less than $40 \%$ (Raun et al. 2002). The low recovery efficiency of $\mathrm{N}$ is associated with its losses through leaching, denitrification, volatilization and soil erosion (Fageria and Baligar 2005). According to Abbasi et al. (2013), the N recovery efficiencies were $24-48 \%$ depending the N-fertiliser forms. Zhu and Wen (1992) reported that nitrogen use efficiency in cereals (maize, wheat, rice) ranged from $28 \%$ to $41 \%$.

The NP and NPK fertilisers resulted in generally higher yields and better NUE than the $\mathrm{N}$ and $\mathrm{NK}$ in both wheat and maize production, which demonstrates the importance of $\mathrm{P}$ (Duan et al. 2014). According to Schröder et al. (2011), farmers fear crop yield losses due to $\mathrm{P}$ equilibrium fertilization because fertilisers seem to have a low $\mathrm{P}$ use efficiency.

In China, results of Li et al. (1998) and Zhu and Wen (1992) in 165 field trials of wheat, maize and rice showed that $\mathrm{P}$ use efficiency ranged from $3.0 \%$ to $49.3 \%$, with an average of $13.1 \%$.

Potassium (K), along with nitrogen $(\mathrm{N})$ and phosphorus $(\mathrm{P})$, is one of the three major plant macroelements. To meet an increasing crop yield demand (Grote et al. 2005), high input of inorganic $\mathrm{N}$ and $\mathrm{P}$ fertiliser has resulted in their low use efficiency and an imbalance of NPK in plants and the soil system (Dobermann et al. 1996; Fan et al. 2005; Wang et al. 2007a, b). Many experiments proved that $\mathrm{K}$ fertiliser can remain in the soil for years after application (Tenkorang and Lowenberg-DeBoer 2009). For a productivity of wheat at 2-5 $\mathrm{t} \mathrm{ha}^{-1}$ or maize at 3-6 $\mathrm{tha}^{-1}, 13-26$ or $9-17 \mathrm{~kg} \mathrm{~K}^{-1}$ were required to produce $1.0 \mathrm{t} \mathrm{ha}^{-1}$ wheat or maize (Zhang et al. 2011). However, $\mathrm{K}$ taken up by the aboveground parts of plants is assimilated mainly into the straw and not into the grain (Jouany et al. 1996). Application of $\mathrm{K}$ significantly increased the average maize yields by 15.1 and $13.8 \%$ in the 113 and $225 \mathrm{~kg} \mathrm{ha}^{-1} \mathrm{~K}_{2} \mathrm{O}$ treatments, respectively. Mean $\mathrm{K}$ recovery efficiency decreased from $37.3 \%$ to $28.5 \%$ when the $\mathrm{K}$ doses increased from 113 to $225 \mathrm{~kg}$ $\mathrm{ha}^{-1} \mathrm{~K}_{2} \mathrm{O}$ (Qiu et al. 2014). The potassium use efficiency in China was about $50 \%$ (Zhu and Wen 1992; Li et al. 1998). K efficiency ranged from $4.5 \%$ to $82.8 \%$, and the average was $27.3 \%$.

The objectives of this study were to investigate the NPK uptake of different maize hybrids in different crop years and to study NPK efficiency at different nutrient levels (including control = non-fertilized) in maize production.

\section{Materials and Methods}

In 1983, a long-term trial on calcareous chernozem soils was set up in the Hajdúság (Eastern Hungary), $15 \mathrm{~km}$ from Debrecen (latitude $47^{\circ} 33^{\prime} \mathrm{N}$, and longitude $21^{\circ} 27^{\prime} \mathrm{E}$ ). The chernozem soil of the experimental area contains $2.7-2.8 \%$ humus, and total depth of the humus enriched horizon was about $0.8 \mathrm{~m}$ (Table 1). When the trial was set up, the soil 


\begin{tabular}{|c|c|c|c|c|c|c|}
\hline \multicolumn{2}{|c|}{ 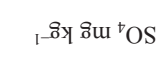 } & $\stackrel{n}{2}$ & $\stackrel{m}{a}$ & 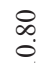 & $\stackrel{n}{\alpha}$ & $\stackrel{\infty}{\stackrel{s}{i}}$ \\
\hline \multicolumn{2}{|c|}{ I- 8 y ou uW } & $\stackrel{\infty}{\underset{\sim}{*}}$ & ๖ & ले & $\pi$ & t \\
\hline \multicolumn{2}{|c|}{ 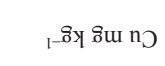 } & $\infty$ & 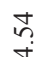 & ț & $\stackrel{+}{\mathrm{i}}$ & to \\
\hline \multicolumn{2}{|c|}{ I-ฮิy ถิน UZ } & $\underset{\substack{\infty \\
\text { i }}}{ }$ & $\stackrel{\infty}{\infty}$ & $\begin{array}{l}\infty \\
n \\
0\end{array}$ & $\stackrel{\infty}{+}$ & $\stackrel{+}{\infty}$ \\
\hline \multicolumn{2}{|c|}{${ }_{1}-\delta y_{y} \delta \mathrm{u} \mathrm{e}_{\mathrm{N}}$} & $\underset{\infty}{\infty}$ & గ్రి & 苑 & $\stackrel{\infty}{\dot{\sigma}}$ & $\begin{array}{l}\circ \\
\text { तु }\end{array}$ \\
\hline \multicolumn{2}{|c|}{ 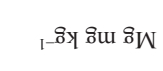 } & 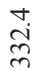 & $\begin{array}{l}+\dot{0} \\
\stackrel{8}{o}\end{array}$ & $\begin{array}{l}0 \\
\dot{0} \\
\dot{0}\end{array}$ & $\stackrel{\stackrel{\leftrightarrow}{+}}{\underset{\sim}{*}}$ & $\begin{array}{l}0 \\
\dot{0} \\
\stackrel{\sim}{0}\end{array}$ \\
\hline \multirow{2}{*}{ 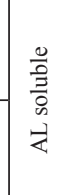 } & $\begin{array}{l}\frac{b 0}{b 0} \\
\frac{b}{b 0} \\
g\end{array}$ & $\stackrel{\infty}{\stackrel{\sim}{~}}$ & $\begin{array}{l}0 \\
\stackrel{\Xi}{I}\end{array}$ & 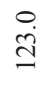 & $\begin{array}{l}\stackrel{0}{\alpha} \\
\text { a }\end{array}$ & 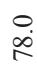 \\
\hline & $\begin{array}{l}\sigma_{b D} \\
\frac{d}{b D} \\
g\end{array}$ & $\stackrel{+}{\stackrel{m}{n}}$ & $\stackrel{\circ}{\stackrel{\infty}{+}}$ & $\stackrel{+}{\stackrel{+}{+}}$ & $\stackrel{\infty}{\stackrel{m}{m}}$ & $\stackrel{\circ}{m}$ \\
\hline \multicolumn{2}{|c|}{ ถิy ภิ } & तु & $\stackrel{+}{\stackrel{7}{~}}$ & $\stackrel{8}{:}$ & $\tilde{\sigma}$ & $\stackrel{\infty}{\stackrel{\sim}{\sim}}$ \\
\hline \multicolumn{2}{|c|}{$\%$ N IвłOL } & 응 & $\stackrel{\overbrace{}}{\stackrel{\overbrace{}}{0}}$ & $\begin{array}{l}0 \\
\stackrel{0}{0} \\
0\end{array}$ & 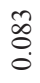 & 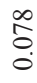 \\
\hline \multicolumn{2}{|r|}{$\%$ snun $_{\mathrm{H}}$} & $\stackrel{\circ}{i}$ & $\stackrel{0}{i}$ & $\stackrel{\overbrace{}}{\leftrightarrow}$ & \& & है? \\
\hline \multicolumn{2}{|r|}{$\%{ }^{\varepsilon} \mathrm{O} \supset^{\mathrm{e}} \mathrm{J}$} & 0 & 0 & 0 & กิ & $\stackrel{n}{i}$ \\
\hline \multicolumn{2}{|c|}{ 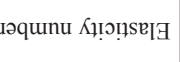 } & $\stackrel{\circ}{\dot{f}}$ & $\begin{array}{l}\circ \\
\dot{j}\end{array}$ & $\begin{array}{l}\dot{q} \\
\dot{q}\end{array}$ & $\begin{array}{l}0 \\
\dot{f} \\
+\end{array}$ & $\ddot{\forall}$ \\
\hline \multicolumn{2}{|r|}{ (IગY) $\mathrm{H}^{\mathrm{d}}$} & to & $\begin{array}{l}\text { D. } \\
\text { గె. }\end{array}$ & $\begin{array}{l}\infty \\
n \\
n\end{array}$ & $\stackrel{\overbrace{}}{N}$ & 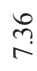 \\
\hline \multicolumn{2}{|c|}{ 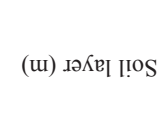 } & 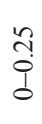 & $\begin{array}{l}0 \\
n \\
0 \\
n \\
n \\
0\end{array}$ & $\begin{array}{l}n \\
\vdots \\
0 \\
1 \\
n \\
0\end{array}$ & $\begin{array}{l}8 \\
\dot{\pi} \\
\text { n } \\
\dot{0}\end{array}$ & 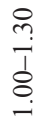 \\
\hline
\end{tabular}

Cereal Research Communications 45, 2017 
contained $130 \mathrm{mg} \mathrm{kg}^{-1}$ AL-soluble $\mathrm{P}_{2} \mathrm{O}_{5}$ and $240 \mathrm{mg} \mathrm{kg}^{-1}$ AL-soluble $\mathrm{K}_{2} \mathrm{O}$. The calcareous chernozem soil is characterized by a specific plasticity index $\left(\mathrm{A}_{\mathrm{K}}\right)$ of 40 and nearly neutral $\mathrm{pH}\left(\mathrm{pH}_{\mathrm{KCl}}=6.46\right)$. The soil has favourable water management characteristics.

During the long-term trial, we applied treatment with 6 nutrient doses. In addition to the control treatment, a basic dose of $\mathrm{N}=30 \mathrm{~kg} \mathrm{ha}^{-1}+\mathrm{P}_{2} \mathrm{O}_{5}=22.5 \mathrm{~kg} \mathrm{ha}^{-1}+\mathrm{K}_{2} \mathrm{O}=26.5$ $\mathrm{kg} \mathrm{ha}^{-1}$ was applied in double, triple, quadruple and quintuple quantities. In the trial, among these doses, the following treatments were examined:

\begin{tabular}{|l|c|c|c|}
\hline \multirow{2}{*}{} & $\mathrm{N}$ & $\mathrm{P}_{2} \mathrm{O}_{5}$ & $\mathrm{~K}_{2} \mathrm{O}$ \\
\cline { 2 - 4 } & \multicolumn{3}{|c|}{$\mathrm{kg} \mathrm{ha}^{-1}$} \\
\hline Control & 0 & 0 & 0 \\
\hline $\mathrm{N}_{90}+\mathrm{PK}$ & 90 & 67.5 & 79.5 \\
\hline $\mathrm{N}_{150}+\mathrm{PK}$ & 150 & 112.5 & 132.5 \\
\hline
\end{tabular}

Nitrogen fertiliser was applied 50\% in the autumn and 50\% in the spring, before sowing. The full amounts $(100 \%)$ of phosphorus and potassium were applied in the autumn before ploughing.

In the long-term trial, the above ground phyto-production and the grain yield of two hybrids, P 9494 (FAO 390) and SY Afinity (FAO 470), were determined in the 2013 and 2014 crop years. The trial was arranged in a split-split-plot design. The gross and net plot areas were $9.12 \mathrm{~m}^{2}$ and $7.60 \mathrm{~m}^{2}$, respectively. The trial involved four repetitions. The forecrop was winter wheat. The optimal agricultural elements (tilling, sowing, crop protection, harvesting) were used, which matched to modern maize production.

Important weather information for the trial years are shown in Tables 2 and 3. Before the 2013 growing season, the amount of precipitation was exceptionally high $(332.7 \mathrm{~mm})$,

Table 2. Rainfall before and during vegetation period of maize (Debrecen)

\begin{tabular}{|c|c|c|c|c|c|c|c|c|}
\hline \multirow{2}{*}{ Crop year } & \multirow{2}{*}{$\begin{array}{c}\text { Rainfall before } \\
\text { vegetation period } \\
\end{array}$} & \multicolumn{7}{|c|}{ Rainfall (mm) } \\
\cline { 5 - 10 } & (Oct.-March) (mm) & April & May & June & July & Aug. & Sept. & Total \\
\hline 2013 & 332.7 & 40.8 & 68.7 & 30.8 & 15.6 & 32.2 & 47.6 & 242.9 \\
\hline 2014 & 167.1 & 39.6 & 69.4 & 7.9 & 128.0 & 44.8 & 95.7 & 385.4 \\
\hline $\begin{array}{c}30 \\
\text { average }\end{array}$ & 220.2 & 42.4 & 58.8 & 79.5 & 65.7 & 60.7 & 38.0 & 345.1 \\
\hline
\end{tabular}

Table 3. Monthly average temperature during vegetation period of maize (Debrecen)

\begin{tabular}{|c|c|c|c|c|c|c|}
\hline \multirow{2}{*}{ Crop year } & \multicolumn{7}{|c|}{ Monthly average temperature $\left({ }^{\circ} \mathrm{C}\right)$} \\
\cline { 2 - 7 } & April & May & June & July & Aug. & Sept. \\
\hline 2013 & 12.0 & 16.6 & 19.6 & 21.2 & 21.5 & 14.0 \\
\hline 2014 & 12.3 & 15.4 & 19.0 & 21.2 & 19.8 & 16.7 \\
\hline 30 years average & 10.7 & 15.8 & 18.7 & 20.3 & 19.6 & 15.8 \\
\hline
\end{tabular}


which could beneficially compensate the average amount $(242.9 \mathrm{~mm})$ in the vegetation period, and the poor distribution (68.7 $\mathrm{mm}$ in May, $30.8 \mathrm{~mm}$ in June, $15.6 \mathrm{~mm}$ in July). In 2014 , there was an average amount of rainfall $(167.1 \mathrm{~mm})$ in the period before the growing season, but a significant amount of rainfall $(385.4 \mathrm{~mm})$ fell in the growing season. However, its distribution was unfavourable (69.4 $\mathrm{mm}$ in May, $7.9 \mathrm{~mm}$ in June, $128.0 \mathrm{~mm}$ in July).

The element content $(\mathrm{N}, \mathrm{P}, \mathrm{K})$ of the aboveground phytomass and the grain yield at harvest were determined by the accredited Central Laboratory of Debrecen University. To determine the element content of the maize grain, the following analysis methods were used:

○ Nitrogen: to the MSZ EN ISO 5983-1:2005 standard, with the Kjeldahl method

o Phosphorus: to the MSZ ISO 6491:2001 standard, with photometry

○ Potassium: to the MSZ EN ISO 6869:2001 standard, with atomic absorption The determination of the above ground phytomass element content of the maize used the following methods:

○ Nitrogen: to the MSZ-08-1786-6:1983 standard, with the Kjeldahl method

○ Phosphorus: to the MSZ-08-1783-23:1985 standard, with flame photometry

o Potassium: to the MSZ-08-1783-5:1983 standard

The evaluation of the trial data was carried out with variance analysis using SPSS 13.0 for Windows and Microsoft Excel 2013 programs.

In relation to the nutrient uptake of maize - adapted to experimental field conditions - we established a hypothesis that the plants utilized the quantity of fertiliser provided in the nutrient treatments. To determine the utilisation of macronutrients in the amount of NPK uptake in different fertiliser treatments we compared to the amount of NPK uptake in the control treatment and we used the following formula:

$$
U E_{N P K}=\frac{T_{n}-T_{c}}{F_{n}} \times 100
$$

where $U E_{N P K}$ utilisation efficiency of nutrients (N, P, K) (\%)

$T_{n} \quad$ amount of $\mathrm{N}, \mathrm{P}_{2} \mathrm{O}_{5}, \mathrm{~K}_{2} \mathrm{O}$ uptake $\left(\mathrm{kg} \mathrm{ha}^{-1}\right)$ in " $\mathrm{n}$ " fertiliser treatment

$T_{c} \quad$ amount of $\mathrm{N}, \mathrm{P}_{2} \mathrm{O}_{5}, \mathrm{~K}_{2} \mathrm{O}$ uptake $\left(\mathrm{kg} \mathrm{ha}^{-1}\right)$ in the control treatment

$F_{n} \quad$ the amount of effective ingredient of the nutrients provided with the fertiliser $\left(\mathrm{N}, \mathrm{P}_{2} \mathrm{O}_{5}, \mathrm{~K}_{2} \mathrm{O}\right)\left(\mathrm{kg} \mathrm{ha}^{-1}\right)$

\section{Results}

The macroelement (nitrogen, phosphorus and potassium) content of the aboveground phytomass and grain yield of two maize hybrids of different genetic characteristics (P 9494 and SY Afinity) were examined in two crop years with different weather (2013 and 2014). The obtained experimental results are shown in Table 4. These results showed that both crop years, nutrient supply and genotype affected the element content of the aboveground phytomass and grain yield of maize. The significant amount of precipitation before the growing period in 2013 favourably filled up the water reserves of the calcare- 
ous chernozem soil of the experiment site. As a result, nutrients were able to infiltrate into the soil solution, making it possible for maize hybrids to take them up in the subsequent periods of the vegetation period which were critical from the aspect of nutrient uptake. In comparison with the control treatment (non-fertilised treatment since 1983), N, P and K content increased as a result of fertiliser treatments $\left(\mathrm{N}_{90}+\mathrm{PK}\right.$ and $\left.\mathrm{N}_{150}+\mathrm{PK}\right)$ in the case of both hybrids. In 2013, the $\mathrm{N}$ content of the aboveground crop mass was between $0.350-0.615 \%$, that of the $\mathrm{P}_{2} \mathrm{O}_{5}$ was between $137.5-427.5 \mathrm{mg} \mathrm{kg}^{-1}$, and the $\mathrm{K}_{2} \mathrm{O}$ content was between 5519-6353 mg kg-1. The N, P and $\mathrm{K}$ content of grain was between $0.925-$ $1.190 \%, 2864-4331 \mathrm{mg} \mathrm{kg}^{-1}$ and 4621-5976 mg kg-1 , respectively. No significant difference was observed between the NPK contents of the two examined fertiliser treatments $\left(\mathrm{N}_{90}+\mathrm{PK}\right.$ and $\left.\mathrm{N}_{150}+\mathrm{PK}\right)$ either in the aboveground phytomass or grain yield. The amount of precipitation in 2014 was favourable; however, its distribution (7.9 $\mathrm{mm}$ in June and 128.0 in July) was unfavourable both in terms of the water uptake of maize and the availability of macroelements. In 2014, NPK content increased as a result of fertiliser treatments in comparison with the control treatment in the vegetative and generative organs of maize in both examined genotypes. The macroelement content of the two hybrids showed significant differences in the two examined years. In 2014, the $\mathrm{N}$ content of the vegetative organs was between $0.600-1.305 \%$, their $\mathrm{P}_{2} \mathrm{O}_{5}$ content was between 589.5-1045.5 mg $\mathrm{kg}^{-1}$, while their $\mathrm{K}_{2} \mathrm{O}$ content was between $2703-8068 \mathrm{mg} \mathrm{kg}^{-1}$. The $\mathrm{N}$, P and $\mathrm{K}$ content values of grain yield were $0.820-1.190 \%, 2557-3271 \mathrm{mg} \mathrm{kg}^{-1}$ and $3041-3549 \mathrm{mg} \mathrm{kg}^{-1}$, respectively. During the two years of the experiment, significant differences were observed in the $\mathrm{N}$ content $(0.464 \%$ in 2013 and $0.932 \%$ in 2014$)$ and the $\mathrm{P}_{2} \mathrm{O}_{5}$ content $(315$ $\mathrm{mg} \mathrm{kg}^{-1}$ in 2013 and $813 \mathrm{mg} \mathrm{kg}^{-1}$ in 2014) of the aboveground phytomass, as well as the $\mathrm{K}_{2} \mathrm{O}$ content of the grain yield (5383 mg kg-1 in 2013 and $3290 \mathrm{mg} \mathrm{kg}^{-1}$ in 2014), averaged over the different hybrids and fertiliser treatments. Significantly smaller differences were observed in the $\mathrm{K}_{2} \mathrm{O}$ content of the vegetative organs between the different crop years (6231 $\mathrm{mg} \mathrm{kg}^{-1}$ in 2013 and $5509 \mathrm{mg} \mathrm{kg}^{-1}$ in 2014), as well as the $\mathrm{N}$ content $(1.065 \%$ and $1.047 \%$ ) and $\mathrm{P}_{2} \mathrm{O}_{5}$ content $\left(3408 \mathrm{mg} \mathrm{kg}^{-1}\right.$ and $2980 \mathrm{mg} \mathrm{kg}^{-1}$ ) of the grain.

The amount of aboveground phytomass of maize was determined before harvesting and grain yield was measured during harvesting. Favourable yields were obtained in both crop years, despite the differences in weather. Yields in 2013 exceeded those in 2014 by 1-3 t ha ${ }^{-1}$; i.e., maize hybrids showed a better conversion ratio of the available water stored in the soil during yield formation processes and they also responded more sensitively to the rainfall distribution during the vegetation period. The examined hybrids produced the following yields in each crop year $\left(\mathrm{kg} \mathrm{ha}^{-1}\right)$ :

\begin{tabular}{|l|c|c|c|c|}
\hline \multirow{2}{*}{} & \multicolumn{2}{|c|}{ P 9494 } & \multicolumn{2}{c|}{ SY Afinity } \\
\cline { 2 - 5 } & 2013 & 2014 & 2013 & 2014 \\
\hline Control & 11,923 & 10,218 & 14,550 & 11,355 \\
\hline $\mathrm{N}_{90}+\mathrm{PK}$ & 16,263 & 13,130 & 16,736 & 14,571 \\
\hline $\mathrm{N}_{150}+\mathrm{PK}$ & 15,206 & 13,524 & 17,718 & 13,295 \\
\hline $\mathrm{LSD}_{0.05}$ & \multicolumn{2}{|c|}{1363} & \multicolumn{2}{c|}{1472} \\
\hline
\end{tabular}




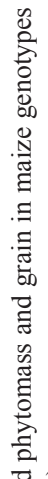

要

कृ

है

ते

氙

ठํㅠ

㻤

(

ธี

.ซี

菊

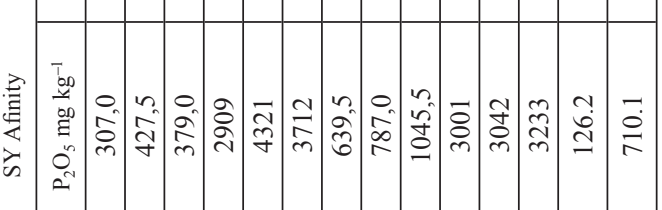

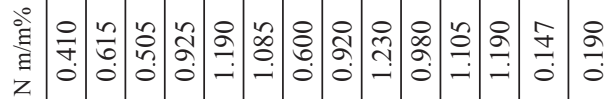

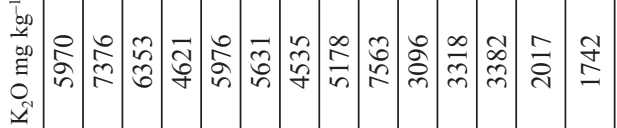

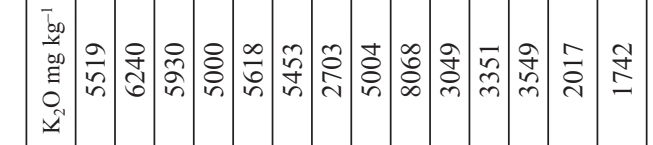

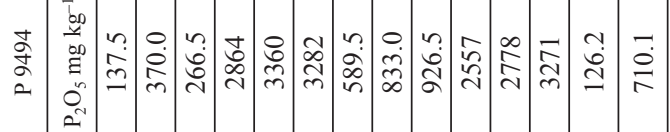

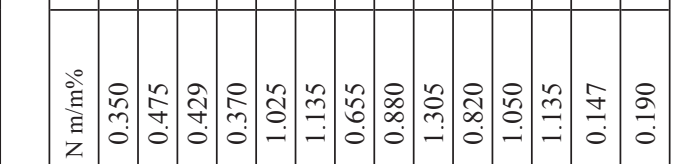

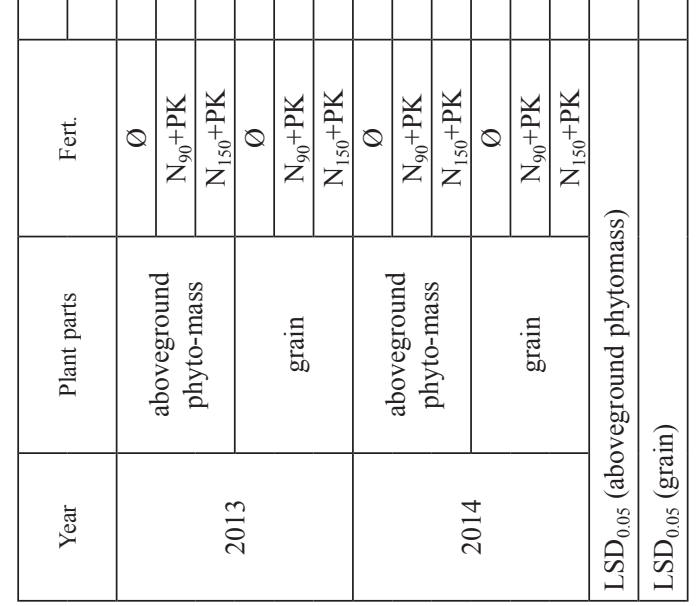

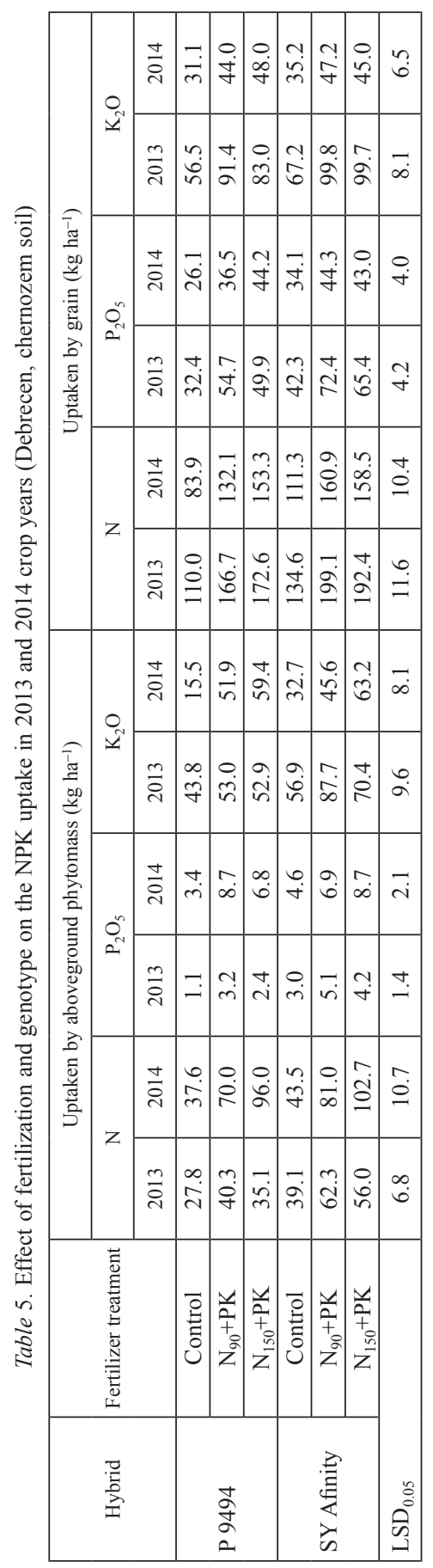


The outstanding water and nutrient management characteristics of chernozem soil are shown by the significantly high yields obtained in the control treatment in both examined years (10.2-11.3 tha $\mathrm{th}^{-1}$ in 2013 and $11.3-14.6 \mathrm{t} \mathrm{ha}^{-1}$ in 2014). These control yields significantly increased further on as a result of the applied fertiliser treatments. Fertilisation resulted in yield surpluses in 2013 (3.2-5.0 $\left.\mathrm{t} \mathrm{ha}^{-1}\right)$ and in 2014 (2.9-3.1 $\left.\mathrm{t} \mathrm{ha}^{-1}\right)$. Liu et al. (2003) and Pepó et al. (2008) found similar experimental effects based on their experimental results.

Table 5 shows the amount of macroelements $\left(\mathrm{kg} \mathrm{ha}^{-1}\right)$ taken up by the aboveground phytomass and grain yield of the examined maize hybrids in 2013 and 2014. The amount of nutrients taken up by the crops was affected by the mass of vegetative and generative organs and their NPK content. In the examined years, the amount of NPK taken up by the crops significantly increased as a result of fertilisation. There were differences in the amount of NPK taken up by the examined hybrids in both crop years. Grain yield withdrew the most significant amount of $\mathrm{N}$ and $\mathrm{P}$ from the chernozem soil, while a significant amount of $\mathrm{K}$ was taken up by vegetative organs. In 2013, the vegetative mass took up 27.8-62.3 $\mathrm{kg} \mathrm{ha}^{-1} \mathrm{~N}, 1.1-5.1 \mathrm{~kg} \mathrm{ha}^{-1} \mathrm{P}_{2} \mathrm{O}_{5}$ and 40.8-87.7 $\mathrm{kg} \mathrm{ha}^{-1} \mathrm{~K}_{2} \mathrm{O}$, depending on the
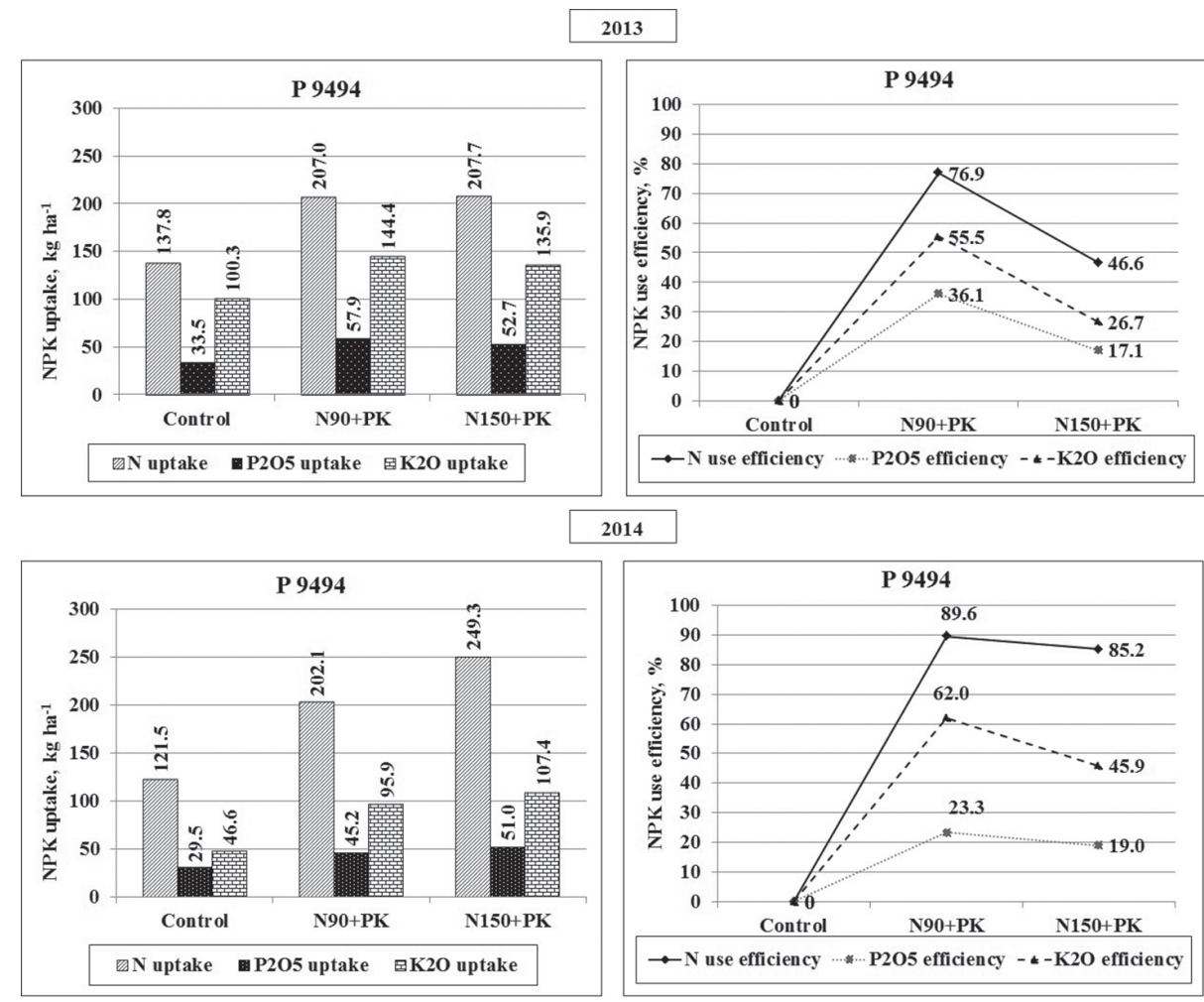

Figure 1. Total NPK uptake $\left(\mathrm{kg} \mathrm{ha}^{-1}\right)$ and NPK use efficiency (\%) of P 9494 maize hybrid (Debrecen, chernozem soil, 2013-2014) 


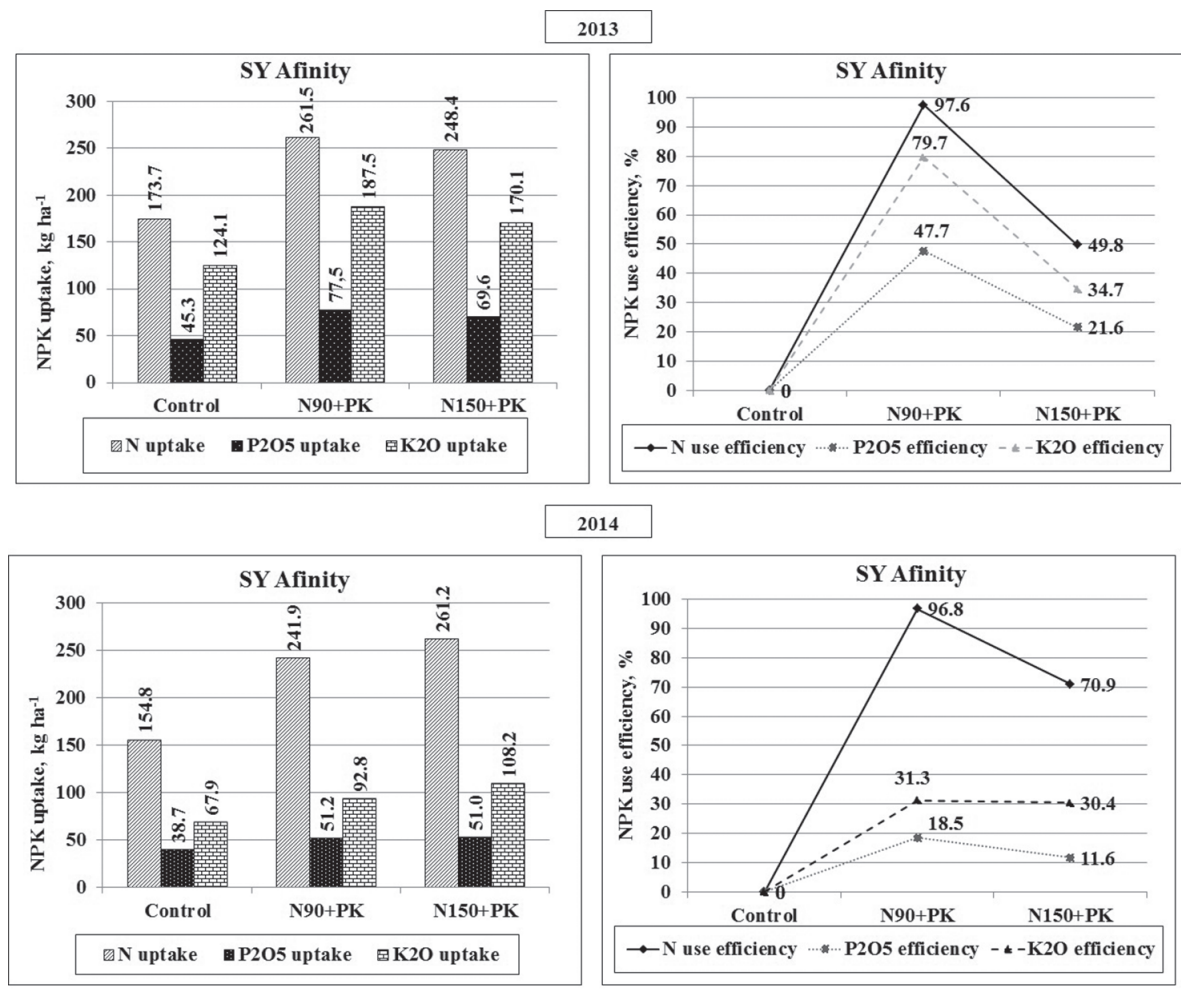

Figure 2. Total NPK uptake $\left(\mathrm{kg} \mathrm{ha}^{-1}\right)$ and NPK use efficiency (\%) of SY Afinity maize hybrid (Debrecen, chernozem soil, 2013-2014)

fertiliser treatments and hybrids, while the same values of 2014 were $37.6-102.7 \mathrm{~kg} \mathrm{ha}^{-1}$, $3.4-8.7 \mathrm{~kg} \mathrm{ha}^{-1}$ and $15.5-63.8 \mathrm{~kg} \mathrm{ha}^{-1}$, respectively. The amount of macroelements (especially phosphorus) uptaken by grain yield was higher in both years. As a result of the applied fertiliser treatments, the amount of NPK taken up by the examined maize hybrids increased, leading to increased amount of macroelements taken up by both vegetative and generative organs. In 2013, the grain yield of the maize hybrids took up 110.0-199.1 kg $\mathrm{ha}^{-1}$ nitrogen, 32.4-72.4 $\mathrm{kg} \mathrm{ha}^{-1}$ phosphorus and 56.5-99.8 $\mathrm{kg} \mathrm{ha}^{-1}$ potassium, while the same values of 2014 were $83.9-160.9 \mathrm{~kg} \mathrm{ha}^{-1}, 26.4-44.3 \mathrm{~kg} \mathrm{ha}^{-1}$ and $31.1-48.0 \mathrm{~kg} \mathrm{ha}^{-1}$, respectively.

Figures 1 and 2 show the total amounts of NPK uptake by maize hybrids (aboveground phytomass + grain yield) in 2013 and 2014 on various nutrient supply levels. The values obtained in the control treatment show the natural nutrient supply capacity of chernozem soil in various crop years and hybrids. Despite the different weather in each crop year, there were only slight differences in the amounts of $\mathrm{N}$ and $\mathrm{P}_{2} \mathrm{O}_{5}$ taken up by the examined maize hybrids and no difference could be detected in the amount of $\mathrm{K}_{2} \mathrm{O}$. However, differences were shown in the nutrient uptake of maize genotypes from the soil. The amount 
of $\mathrm{N}$ taken up by the $\mathrm{P} 9494$ hybrid was between $121.5-137.8 \mathrm{~kg} \mathrm{ha}^{-1}$ in the two examined crop years, while the amount of $\mathrm{P}_{2} \mathrm{O}_{5}$ was $29.5-33.5 \mathrm{~kg} \mathrm{ha}^{-1}$. The amounts of $\mathrm{N}$ and $\mathrm{P}$ taken up by the SY Afinity hybrid from the soil were higher $\left(\mathrm{N}=154.8-173.7 \mathrm{~kg} \mathrm{ha}^{-1}\right.$; $\mathrm{P}_{2} \mathrm{O}_{5}=38.7-45.3 \mathrm{~kg} \mathrm{ha}^{-1}$ ). As regards $\mathrm{K}$ uptake from the $\mathrm{K}$ stock of the soil, there were similarly significant differences between each hybrid, but the crop year effect was also significant. The amount of $\mathrm{K}_{2} \mathrm{O}$ taken up by the $\mathrm{P} 9494$ hybrid in the control treatment was 46.6 and $100.3 \mathrm{~kg} \mathrm{ha}^{-1}$ in 2013 and 2014, respectively, while that of the SY Afinity hybrid was 67.9 and $124.1 \mathrm{~kg} \mathrm{ha}^{-1}$ in 2013 and 2014, respectively. Compared to the control treatment, maize hybrids took up significantly higher amounts of $\mathrm{N}, \mathrm{P}$ and $\mathrm{K}$ in the $\mathrm{N}_{90}+\mathrm{PK}$ and $\mathrm{N}_{150}+\mathrm{PK}$ fertiliser treatments with their above ground phytomass and grain yield altogether. In the applied fertiliser treatments, the P 9494 hybrid took up 202.1$249.3 \mathrm{~kg} \mathrm{ha}^{-1}$ and 207.0-207.7 $\mathrm{kg} \mathrm{ha}^{-1} \mathrm{~N}, 45.2-51.0 \mathrm{~kg} \mathrm{ha}^{-1}$ and 52.7-57.9 $\mathrm{kg} \mathrm{ha}^{-1} \mathrm{P}_{2} \mathrm{O}_{5}$, and 95.9-107.4 $\mathrm{kg} \mathrm{ha}^{-1}$ and 135.9-144.4 $\mathrm{kg} \mathrm{ha}^{-1} \mathrm{~K}_{2} \mathrm{O}$ in 2013 and 2014, respectively. As regards the SY Afinity hybrid, the following respective values were measured: $\mathrm{N}=241.9$ $261.2 \mathrm{~kg} \mathrm{ha}^{-1}$ and $248.4-261.5 \mathrm{~kg} \mathrm{ha}^{-1} ; \mathrm{P}_{2} \mathrm{O}_{5}=51.2-51.7 \mathrm{~kg} \mathrm{ha}^{-1}$ and $69.6-77.5 \mathrm{~kg} \mathrm{ha}^{-1}$; $\mathrm{K}_{2} \mathrm{O}=92.8-108.2 \mathrm{~kg} \mathrm{ha}^{-1}$ and $170.1-187.5 \mathrm{~kg} \mathrm{ha}^{-1}$.

\section{Discussion}

Several ecological and agrotechnical factors affect the amount of nutrients applied with fertilisers (Fageria and Baligar 2005; Cui et al. 2006). Similarly to the scientific results of Zhu and Wen (1992), as well as Yan et al. (2008), notable differences were observed in these experiments with regard to the uptake and utilization ratio of nitrogen from fertilisers (Figs 1 and 2). In 2013, N use efficiency was between 70.9-96.8\%, while it ranged between 46.6-97.6\% in 2014. Based on the 165 field experiments performed by Zhu and Wen (1992), $\mathrm{N}$ use efficiency ranged in an even higher interval (8.9-78.0\%). In both years, the best $\mathrm{N}$ use efficiency was obtained in the case of the biologically and agronomically optimum fertiliser treatment $\left(\mathrm{N}_{90}+\mathrm{PK}\right)$. Higher fertiliser doses $\left(\mathrm{N}_{150}+\mathrm{PK}\right)$ significantly reduced $\mathrm{N}$ use efficiency (especially in 2014). The SY Afinity hybrid showed better $\mathrm{N}$ use efficiency than the P 9494 hybrid in both examined years. The difference between genotypes in terms of $\mathrm{N}$ use efficiency was also shown by the experiment results of Pollmer et al. (1979), Balko and Russell (1980) and Akintoye et al. (1999).

According to international experiment data (Schröder et al. 2011; Duan et al. 2014), of all macroelements, the lowest use efficiency was observed in the case of phosphorus (Figs 1 and 2). Differences were observed between $P$ use efficiency in terms of fertiliser doses, hybrids and crop years. The best $\mathrm{P}$ use efficiency was obtained in the $\mathrm{N}_{90}+\mathrm{PK}$ fertiliser treatment. Higher fertiliser doses $\left(\mathrm{N}_{150}+\mathrm{PK}\right)$ reduced the use efficiency of phosphorus. The SY Afinity hybrid showed slightly lower P use efficiency in 2013 (11.6-18.5\%) than the P 9494 hybrid (19.0-23.3\%). In 2014, P use efficiency was better in general, but SY Afinity showed better results (21.6-47.7\%) than the P 9494 hybrid (17.1-36.1\%). Similarly to these experiments, the scientific results of Zhu and Wen (1992) and Li et al. (1998) obtained moderate P use efficiency (3.0-49.3\%, average: 13.1\%). 
Also, potassium use efficiency ratio values (Figs 1 and 2) showed that (similarly to nitrogen and phosphorus) increasing fertiliser doses reduced $\mathrm{K}$ efficiency in the case of maize hybrids. The most favourable K efficiency was obtained in the $\mathrm{N}_{90}+\mathrm{PK}$ treatment. Based on the experiments of Qiu et al. (2014), it was concluded that increasing fertiliser doses resulted in lower K efficiency (decreasing from $37.3 \%$ to $28.5 \%$ ). Similar to the experiments described in this study, the experiments of Li et al. (1998) and Zhu and Wen (1992) showed that K efficiency ( $\sim 50 \%)$ exceeded the value of P use efficiency $(\sim 13 \%)$. In 2013, $\mathrm{K}$ efficiency was between $30.4-31.3 \%$ in the case of SY Afinity, while it was between $45.9-62.0 \%$ in the case of P 9494; therefore, there was a notable difference between the two genotypes. Also, a difference was found between the two hybrids in terms of K efficiency in 2014, which had a different weather than 2013 (SY Afinity: 34.779.7\%; P 9494: 26.7-55.5\%). Different analyses performed by Li et al. (1998) showed similar results to the results described here in relation to K conversion (4.5-82.8\%, average: $27.8 \%$ ).

Comparing our scientific results with the relevant literature, we pointed out that there were differences in the NPK uptake and the NPK use efficiency of maize genotypes. The NPK utilization of maize hybrids were modified by crop year (mainly the amount of precipitation and its distribution). In our long-term experiment established in 1983, we found that the N-efficiency of maize hybrids varied between 50 and 98\%, P-efficiency between $12-48 \%$ and K-efficiency between $27-80 \%$, respectively. The maize genotypes studied in our long-term experiment gave a different fertiliser response, which is important to take into account in practical management.

\section{References}

Abbasi, M.K., Tahir, M.M., Rahim, N. 2013. Effect of N fertilizer source and timing on yield and N use efficiency of rainfed maize (Zea mays L.) in Kashmir-Pakistan. Geoderma. 195-196:87-93.

Akintoye, H.A., Kling, J.G., Lucas, E.O. 1999. N-use efficiency of single, double and synthetic maize lines grown at four N levels in three ecological zones of West Africa. Field Crops Res. 60:189-199.

Balko, L.G., Russell, W.A. 1980. Effects of rates of nitrogen fertilizer on maize inbred lines and hybrid progeny. I: Prediction of yield responses. Maydica 25:65-79.

Cui, Z.L., Chen, X.P., Li, J.L., Xu, J.F., Shi, L.W., Zhang, F.S. 2006. Effect of N fertilization on grain yield of winter wheat and apparent $\mathrm{N}$ losses. Pedosphere 16:806-812.

Devkota, M., Martius, C., Lamers, J.P.A., Sayre, K.D., Devkota, K.P., Gupta, R.K., Egamberdiev, O., Vlek, P.L.G. 2013. Combining permanent beds and residue retention with nitrogen fertilization improves crop yields and water productivity in irrigated arid lands under cotton, wheat and maize. Field Crop Res. 149:105-114.

Dobermann, A., Cruz, P.C.S., Cassman, K.G. 1996. Fertilizer inputs, nutrient balance, and soil nutrient-supplying power in intensive, irrigated rice systems. I. Potassium uptake and K balance. Nutr. Cycl. Agroecosys. 46:1-10.

Duan, Y., Xu, M., Gao, S., Yang, X., Huang, S., Liu, H., Wang, B. 2014. Nitrogen use efficiency in a wheat-corn cropping system from 15 years of manure and fertilizer applications. Field Crops Res. 157:47-56.

Fageria, N.K., Baligar, V.C. 2005. Enhancing nitrogen use efficiency in crop plants. Advances in Agron. 88:97-185.

Fan, T.L., Stewart, B.A., Payne, W.A., Wang, Y., Luo, J.J., Gao, Y.F. 2005. Long-term fertilizer and water availability effects on cereal yield and soil chemical properties in northwest China. Soil Sci. Soc. Am. J. 69:421-428. 
Grote, U., Craswell, E., Vlek, P. 2005. Nutrient flows in international trade: ecology and policy issues. Environ. Sci. Policy 8:439-451.

Jouany, C., Colomb, B., Bosc, M. 1996. Long-term effects of potassium fertilization on yields and fertility status of calcareous soils of south-west France. Euro. J. Agron. 5:287-294.

Ladha, J.K., Pathak, H., Krupnik, T.J., Six, J., van Kessel, C. 2005. Efficiency of fertilizer nitrogen in cereal production: retrospects and prospects. Adv. Agron. 87:85-156.

Li, Q.K., Zhu, Z.L., Yu, T.R. 1998. Fertilizer Questions in Sustainable Development of Agriculture in China. Jiangxi Science and Technology Press. Jiangxi, China. pp. 3-5.

Li, X.X., Hu, C.S., Delgado, J.A., Zhang, Y.M., Ouyang, Z.Y. 2007. Increased nitrogen use efficiencies as a key mitigation alternative to reduce nitrate leaching in North China Plain. Agric. Water Manage. 89:137-147.

Liu, X.J., Ju, X.T., Zhang, F.S., Pan, J.R., Christie, P. 2003. Nitrogen dynamics and budgets in a winter wheatmaize cropping system in the North China Plain. Field Crops Res. 83:111-124.

Lü, P., Zhang, J.W., Liu, W., Yang, J.S., Su, K., Liu, P., Dong, S.T., Li, D.H. 2011. Effects of nitrogen application on yield and nitrogen use efficiency of summer maize under super-high yield conditions. Plant Nutr. Fertil. Sci. 17:852-860.

Muruli, B.I., Paulsen, G.M. 1981. Improvement of nitrogen-use efficiency and its relationship to other traits in maize. Maydica 26:63-73.

Pepó, P., Vad, A., Berényi, S. 2006. Effect of some agrotechnical elements on the yield of maize on chernozem soil. Cereal Res. Commun. 34:621-624.

Pepó, P., Vad, A., Berényi, S. 2008. Effects of irrigation on yields of maize (Zea mays L.) in different crop rotation. Cereal Res. Commun.. 36:735-738.

Pollmer, W.G., Eberhard, D., Klein, D., Dhillon, B.S. 1979. Genetic control of nitrogen uptake and translocation in maize. Crop Sci. 19:82-86.

Qiu, S., Xie, J., Zhao, S., Xu, X., Hou, Y., Wang, X., Zhou, W., He, P., Johnston, A.M., Christie, P. 2014. Longterm effects of potassium fertilization on yield, efficiency, and soil fertility status in a rain-fed maize system in northeast China. Field Crops Res. 163:1-9.

Raun, W.R., Solie, J.B., Johnson, G.V., Stone, M.L., Mullen, R.W., Freeman, K.W., Thomason, W.E., Lukina, V. 2002. Improving nitrogen use efficiency in cereal grain production with optical sensing and variable rate application. Agron. J. 94:815-820.

Schröder, J.J., Smith, A.L., Cordell, D., Rosemarin, A. 2011. Improved phosphorus use efficiency in agriculture, a key requirement for its sustainable use. Chemosphere 84:822-831.

Tenkorang, F., Lowenberg-DeBoer, J. 2009. Forecasting long-term global fertilizer demand. Nutr. Cycl. Agroecosys. 83:233-247.

Van Groenigen, J.W., Velthof, G.L., Oenema, O., Van Groenigen, K.J., Van Kessel, C. 2010. Towards an agronomic assessment of $\mathrm{N}_{2} \mathrm{O}$ emissions: a case study for arable crops. Eur. J. Soil Sci. 61:903-913.

Wang, X.B., Cai, D.X., Hoogmoed, W.B., Perdok, U.D., Oenema, O. 2007a. Crop residue, manure and fertilizer in dryland maize under reduced tillage in northern China: I. Grain yields and nutrient use efficiencies. Nutr. Cycl. Agroecosys. 79:1-16.

Wang, X.B., Hoogmoed, W.B., Cai, D.X., Perdok, U.D., Oenema, O. 2007b. Crop residue, manure and fertilizer in dryland maize under reduced tillage in northern China: II. Nutrient balances and soil fertility. Nutr. Cycl. Agroecosys. 79:17-34.

Yan, X., Jin, J., He, P., Liang, M. 2008. Recent advances on the technologies to increase fertilizer use efficiency. Agricult. Sci. in China. 7:469-479.

Zhang, H.M., Yang, X.Y., He, X.H., Xu, M.G., Huang, S.M., Liu, H., Wang, B.R. 2011. Effect of long-term potassium fertilization on crop yield and potassium efficiency and balance under wheat-maize rotation in China. Pedosphere 21:154-163.

Zhu, Z.L., Wen, Q.X. 1992. Soil Nitrogen in China. Jiangsu Science and Technology Press. Jiangsu, China. pp. 228-231. 